(works general manager responsible for Calder) compared the time scales for commissioning the first Windscale pile with those for Calder. Despite the much greater complexity of the latter, the work had gone remarkably smoothly. This, together with the fact that the operating figures were very near the design figures, convinced him that he had a very satisfactory plant to operate.

On this note of mixed satisfaction with the present and high expectation for the future, Sir John Cockcroft closed a highly successful and possibly historic conference.

\title{
OBITUARIES
}

\section{Prof. C. A. Chant}

WiтH the death of Clarence Augustus Chant, professor emeritus of astrophysics of the University of Toronto, on November 18, in his ninety-second year, Canadian astronomy has lost the one who has often been referred to as its 'dean'. He was the founder of the Department of Astronomy at the University of Toronto and of the David Dunlap Observatory and editor for fifty years of the Journal of the Royal Astronomical Society of Canada. More than anyone else, he had been responsible for the growth of that Society from a small Toronto group to a nation-wide society which is truly representative of all Canadian astronomy, both professional and amateur.

Chant was born near Toronto on May 31, 1865. Educated in country schools, he was a school teacher for a year before entering the University of Toronto. After his graduation as an honours student in mathe. matics and physics in 1890, he was appointed in the following year to the teaching staff in physics at the University. During his early years there he experimented with Hertzian waves and is credited with transmitting the first wireless message in Canada.

By 1904 Chant had become engrossed in astronomy, had become president of the newly chartered Royal Astronomical Society of Canada and had won recognition for astronomy in the creation by the University Senate of a teaching department and of a graduating option of the mathematics and physics honours course. Under his enthusiastic leadership, the Royal Astronomical Society of Canada, then restricted to Toronto, expanded to include centres all across the country and embarked upon publication of its Journal and annual "Handbook", both of which were edited by Chant from their inception in 1907. At the same time, he expanded the teaching of astronomy at the University, and among his students were numbered nearly all the Canadian astronomers who were to develop observational astronomy in Canada during the first half of the century-at Ottawa, at Victoria and later at Toronto. Chant himself felt hampered at Toronto by the lack of an observatory, and as early as 1912 he began to strive to acquire for the University a major research telescope. It was not until 1928 that these efforts promised to come to fruition, when Mrs. Jessie Donalda Dunlap offered to present to the University, in memory of her late husband, an observatory to bear his name. Chant devoted the next seven years to the plans for this observatory and its 74-in. reflector, which was built to his specifications in Britain by Sir Howard Grubb Parsons and Co., Ltd., the first of a series of similar instruments made by that firm. The David Dunlap Observatory was opened on May 31, 1935, and Chant, its first director, retired at the age of seventy.

During the years when he lacked adequate observing facilities in Toronto, Chant made a number of visits to American observatories and led five solar eclipse expeditions. The most successful of these was an expedition to Australia for the 1922 eclipse ; he and R. K. Young obtained at that time one of the first verifications of the Einstein prediction regarding the deflexion of starlight by the Sun's gravitational field. He also had success as a writer of popular science articles, of school and college physics text-books and of an excellent popular astronomy book, "Our Wonderful Universe", which was published in Canada, in Britain and in five foreign language translations.

Chant's degrees included a Ph.D. from Harvard and an honorary LL.D. from Toronto. $\mathrm{He}$ was Fellow of the Royal Society of Canada, of the Royal Astronomical Society in Britain, of the American Physical Society, and member of the Société Astro. nomique de France and of the Astronomische Gesellschaft.

Since 1935 Chant had lived in retirement at Observatory House near the David Dunlap Observatory. Until a few weeks before his death he had maintained an active interest in the work of the Observatory and had continued his writing and his editorial activities. His mind remained alert and occupied with the many things that interested him, but especially with astronomy, the science to which he had devoted his long life. J. F. Heand

\section{Lady Flinders Petrie}

By the death of Lady Flinders Petrie on Novem. ber 23, the archæological world has lost a striking pərsonality. As a girl, her interest naturally turned to geology owing to the friendship between her family and that of Prof. Seeley, the geologist, and this interest remained with her all her life. But after her marriage she devoted herself to her husband's work. She accompanied him in all his expeditions to Egypt, to Sinai, to Palestine, enjoying the sense of freedom which camp-life gives.

When working with her husband she did not teke part in the actual excavation, but helped in the measuring of buildings and in the drawing of the finds. She always called the roll of the workmen as they came at sunrise to the excavation, she visited the work at intervals during the day, and in the evening, when the workmen brought the day's finds to the camp to be inspected and their value assessed by Petrie, she kept tally of the amount due to each man. She was present at all the spectacular findsthe jewellery of the First Dynasty, the treasure of Lahun, and that dramatic moment when Petrie identified an apparently worthless broken mud figure as an ivory statuette, the only known portrait of the builder of the Great Pyramid. She did two excavations herself : the first when she and I together opened up the Osireion at Abydos, and in the fol- 
lowing year she cleared seven sculptured tombchapels at Saqqara. But when her husband left the Egypt Exploration Society, the whole burden of raising funds for his work fell on her. It was then that she developed that gift of rousing not merely interest but also enthusiasm, and it was through her efforts that he was able to continue his work, with only the break of the First World War, until within three years of his death. After his death she devoted herself to preparing his unfinished manuscripts for publication, and on her return to England $\operatorname{sh} \theta$ saw them through the press.

Lady Flinders Petrie herself wrote two books. Her report on her excavations at Saqqara was published under the name of "Seven Memphite Tomb. Chapels". In this the carefully drawn plans and details of building show her accurate work, and the letterpress also shows the same meticulous accuracy. Her other book, "Early Egyptian Hieroglyphs", though less imposing in size, is perhaps the more important of the two. For anyone studying the actual meaning of the hieroglyphic signs and the objects which they represent, this book is indispensable. The signs are drawn from examples of the First and Second Dynasties, and the identification of the object which the sign represents often throws light on the root meaning of the sign when used in later writings. It is a book with which every student of Egyptology should be well acquainted.

\section{A. Murray}

\section{Prof. O. W. Tiegs, F.R.S.}

WrтH the death on November 5 of Prof. $O$. W. Tiegs, Australia has lost a great zoologist. An avowed disciple of descriptive morphology during an age when most biologists are turning more and more towards experimentation, Tiegs has an assured place in the history of zoology.

Born in Queensland in 1897, Oscar Werner Tiegs received his early education at Brisbane Grammar School and then proceeded to the University of Queensland, obtaining his B.Sc. with first-class honours in biology in 1919. It was his original intention to enter the medical profession; but, fortunately for zoological science, there was no medical school in Queensland and so he decided to continue his studies in zoology. After carrying out postgraduate work on insect metamorphosis and on the biological control of prickly pear, he joined the staff of the Zoology Department of the University of Adelaide in 1922, obtaining his D.Sc. from that University in 1925. In the same year, he was appointed to a lectureship in the University of Melbourne. Three years later, he was awarded the Syme Prize and Medal, one of Australia's foremost scientific prizes. The award of a Rockefeller Fellowship enabled him to spend a year working in Europe. Most of this time was spent in Cambridge and Utrecht. After his return to Melbourne, he was appointed associate professor of zoology, a post which he held until 1948, when he was called to the chair on the retirement of the late Prof. W. E. Agar.

Prof. Tiegs was elected a Fellow of the Royal Society in 1944 and was a foundation member of the Australian Academy of Science. His research activities were mainly in the field of nerve and muscle histology and of arthropod embryology. His study of the embryology of myriapods and insects, recorded in a magnificent series of memoirs, culminated in the development of his well-known views on the ancestry of the insects. Just a few days before his death, he completed a masterly review of the whole problem of arthropod evolution. In some of his more recent research activities, he returned to a study of the histogenesis of flight muscles in insects. All his published work was superbly illustrated, for Tiegs had great artistic ability. To watch the metamorphosis of a plate, from the rough pencil sketches made at the binocular microscope to the finished work ready for reproduction, was indeed a fascinating spectacle.

By nature, Tiegs was a shy and reserved man, more at home in the laboratory than at the committee meeting or the social function. He possessed a keen sense of humour and a fine appreciation of art, literature and music. To share with him the pleasures of a musical evening was a joy indeed. His death is a severe blow to zoology and a great personal loss to those who have enjoyed the privilege of working in his department.

A. M. Clark

\section{Mr. George Patchin}

George Patchin, born in 1877, died on September 7 after a long illness. He entered the Royal School of Mines in 1895 and obtained the associateship of the College with first-class honours in 1898. He was also awarded the Bessemer Medal, presented to the best student of the year.

In 1898, Patchin was appointed lecturer in metallurgy at Birkbeck College, London, and remained there until 1912 when the department was closed and the work was transferred to the Metallurgy Department of the Sir John Cass Technical Institute. He joined the Cass department under the late Mr. C. O. Bannister, whom he succeeded in 1919. Patchin published several papers, chiefly on cupellation, both independently and in collaboration with Bannister. During the First World War, he undertook investigations in the Department for the Inventions Branch of the Ministry of Munitions and served on several committees of that Ministry.

He succeeded the late Dr. C. A. Keane as principal of the Sir John Cass Institute in 1926, but continued also in his post as head of the Metallurgy Department, and he held both posts until his retirement in 1945 . He was greatly attached to the interests of Sir John Cass's Foundation, and in his work for the Institute during more than thirty years his constant purpose was to advance the standards of the courses both in his own Department and later in the other departments which came under his care.

In 1931, Patchin was engaged in an important extension of the Institute building. He devoted great care to this work, which unfortunately had to be considerably curtailed because of the economic depression; but he justifiably took great pride in the results achieved. During the Second World War, much of the normal work of the Institute had to cease. The training of navigating officers for the merchant navy and of radar mechanics for the R.A.F. was undertaken under conditions that were often both difficult and uncomfortable. It became impracticable to hold most evening classes, and students attended their courses in the science departments at week-ends. Although there was major damage to the building, particularly in an air raid in 1941, he never allowed work to be brought to a standstill.

Patchin took a particular interest in all branches of metallurgical education. He was an active member 